\title{
Biotransformation of Mycotoxins in the Reconstituted Cytochrome P-450 System
}

\author{
Y. UENO* \\ 上 野 芳 夫*: \\ 再構成チトクローム P-450 系によるマイコトキシンの生転換

\begin{abstract}
Summary
Metabolic transformation of ochratoxin A (OA) and emodin (EM) was investigated in the microsomal and reconstituted cytochrome $\mathrm{P}-450$ systems of the rat liver. In the microsomal system, OA was transformed into $4(\mathrm{R})$ - and $4(\mathrm{~S})-4$-hydroxy-OAs, and 3methylcholanthrene ( $3 \mathrm{MC}$ ) as well as PCB enhanced the microsomal hydroxylation of $\mathrm{OA}$ to $4(\mathrm{R})-4$-hydroxy-OA. In the reconstituted cytochrome $\mathrm{P}-450$ system, cytochrome P-450 II-a (maximal CO-differential spectrum at $448.0 \mathrm{~nm}$ and high-spin form), fractionated from PCB-microsomes, selectively catalyzed the hydroxylation of $\mathrm{OA}$ and EM into 4 (R)-4-hydroxy-OA and 2-hydroxy-EM, respectively.
\end{abstract}

In the preceding papers ${ }^{1,2)}$, we reported that $\mathrm{AFB}_{1}$ was biotransformed into DNA-binding form (s) and a hydroxylated metabolite, $\mathrm{AFM}_{1}$, in the reconstituted cytochrome $\mathrm{P}-450$ system composed of cytochrome $\mathrm{P}-450 \mathrm{~s}$, NADPH-cytochrome $\mathrm{C}$ reductase $\left(f_{p T}\right)$, deoxycholate, and others, and that the activation of $\mathrm{AFB}_{1}$ into DNA-binding form (s) and the hydroxylation to $\mathrm{AFM}_{1}$ were selectively catalyzed by cytochrome P-450 I-a (maximal CO-differential sepectrum at $450.0 \mathrm{~nm}$ and low-spin form) and cytochrome P-450 II-a $(448.0 \mathrm{~nm}$ and high-spin form), respectively.

The hepatic microsomes derived from rats transformed emodin (EM; 1,3,8-trihydroxy-6-methylanthraquinone) into at least 10 anthraquinoid metabolites, and among these metabolites 2-hydroxy$\operatorname{EM}(1,2,3,8$-tetrahydroxy-6-methyl-anthraquinone)

* Department of Toxicology and Microbial Chemistry, Faculty of Pharmaceutical Sciences, Tokyo University of Science (Ichigaya, Tokyo 162) 東京理科大学薬学部・毒性・微生物化学教室 ( 162 東京都新宿区市谷) is a direct-acting mutagen in Ames assay ${ }^{3,4)}$.

In order to characterize the role of cytochrome $\mathrm{P}-450$ isozymes in metabolic transformation of mycotoxins, we described the biotransformation of ochratoxin $\mathrm{A}(\mathrm{OA})$ and $\mathrm{EM}$ in the reconstituted cytochrome $\mathrm{P}-450$ system.

\section{Materials and Methods}

Mycotoxins: $\mathrm{OA}$ and EM were isolated from. Aspergillus ochraceus and rhubarb, respectively. Standard $4(\mathrm{R})$ - and $4(\mathrm{~S})-4$-hydroxy-OAs were kindly gifted by Dr. Størmer (University of Oslo).

Enzymes and assay: Microsomes were prepared from the livers of rats $^{1)}$, and cytochrome P-450 s were fractionated from the livers of PCB (Kanechlore 400)-induced rats $^{5}$. In the microsomal system, potassium phosphate buffer $(\mathrm{pH} \mathrm{7.2)} 100$ $\mu$ moles, $\mathrm{MgCl}_{2} 2.5 \mu$ moles, NADP $2.5 \mu$ moles, glucose-6-phosphate (G-6-P) $5 \mu$ moles, G-6-P dehydrogenase 1 unit, microsomal protein $2-3 \mathrm{mg}$, and OA 0.125 or EM $37 \mu$ moles, in total volume of 1.0 $\mathrm{ml}$, were incubated at $37^{\circ} \mathrm{C}$ for $20-60 \mathrm{~min}$. In the 
reconstituted cytochrome $\mathrm{P}-450$ system, cytochrome P-450 0.1 nmole, fрт 0.75 unit, dilauroyl L-3 phosphatidyl choline $15 \mu \mathrm{g}$, sodium deoxycholate $50 \mu \mathrm{g}$, EDTA $0.05 \mu$ mole, $\mathrm{MgCl}_{2} 7.5 \mu$ moles, NADP 0.25 $\mu$ mole, G-6-P $2.5 \mu$ moles, G-6-P dehydrogenase 0.5 unit, potassium phosphate buffer $(\mathrm{pH} 7.4) 25$ $\mu$ moles, and OA 39 or EM $18 \mu$ moles, in total volume of $0.5 \mathrm{ml}$, were incubated at $37^{\circ} \mathrm{C}$ for 60 $\min$.

Analysis of metabolites: As for the metabolism of $\mathrm{OA}$, the reaction was terminated by an addition of $0.5 \mathrm{ml}$ of $2 \mathrm{~N} \mathrm{HCl}$ solution, and the metabolites were extracted with methanol-chloroform mixture $(2: 1)$ and followed by TLC analysis. Silicagel plates were developed in chloroform-ethyl acetateformic acid (10:3:1, v/v). After an additional development with the same solvent, the metabolites were determined by fluorodensitometry (CS-910 dual-wavelength chromatoscanner, Shimadzu; excitation at $345 \mathrm{~nm}$ and emission at $450 \mathrm{~nm}$ ). The reaction mixture of $\mathrm{EM}$ metabolism was acidified with $\mathrm{HCl}$, followed by extraction with ethyl acetate extract, and the ethyl acetate extract was analyzed by TLC. The silicagel plate, pretreated with $1 \mathrm{~N}$ oxalic acid, was developed in chloroformcyclohexane-dioxane $(10: 1: 1)$, and the metabolites were quantitated at $450 \mathrm{~nm}$.

\section{Results and Discussion}

TLC analysis of the microsomal metabolites of OA revealed, besides of OA remained (Rf. 0.52), 4 (S)-4-hydroxy-OA (Rf. 0.37), 4(R)-4-hydroxyOA (Rf. 0.31), and a polar metabolite (Rf. 0.05). These two hydroxylated metabolites were comigrated with the standards under different solvent systems such as chloroform-ether-acetic acid (17: $5: 1)$ and toluene-ethyl acetate-formic acid (6:3: 1).

Fig. 1 showed the hydroxylating activity of hepatic microsomes prepared from the control and induced rats. In the control microsomes, the formation of $4(\mathrm{R})$-4-hydroxy-OA was about 4 times higher than $4(\mathrm{~S})-4$-hydroxy-OA, and it was enhanced in $\mathrm{PCB}-$ and $3 \mathrm{MC}$-induced rats. In the

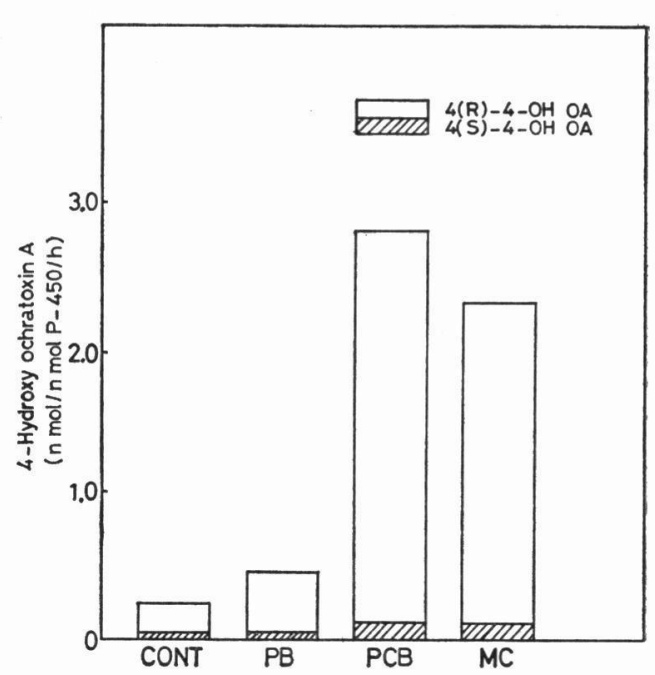

Fig. 1. Microsomal hydroxylation of ochratoxin $\mathrm{A}$

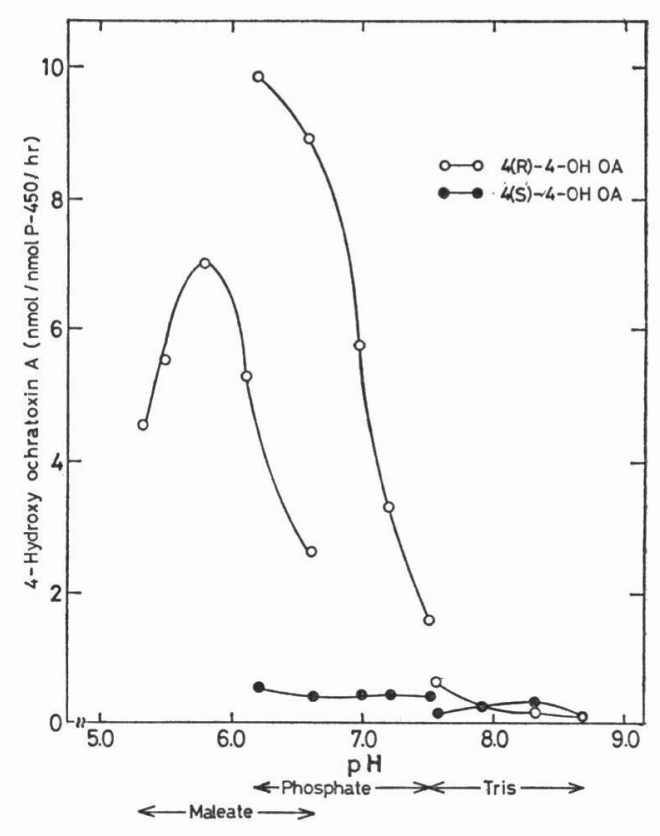

Fig. 2. $\mathrm{pH}$ Dependency of the hydroxylation reaction of ochratoxin $A$ in the hepatic microsomes derived from $3 \mathrm{MC}$-induced rats

$3 \mathrm{MC}$-microsomes, the maximal production of 4 (R)-4-hydroxy-OA was observed at $\mathrm{pH} 6.0$ (Fig. 2). Since the maximal production of $\mathrm{AFM}_{1}$ and 2-hydroxy-EM was observed at $\mathrm{pH} 8.0^{6}$ ) and $\mathrm{pH}$ 


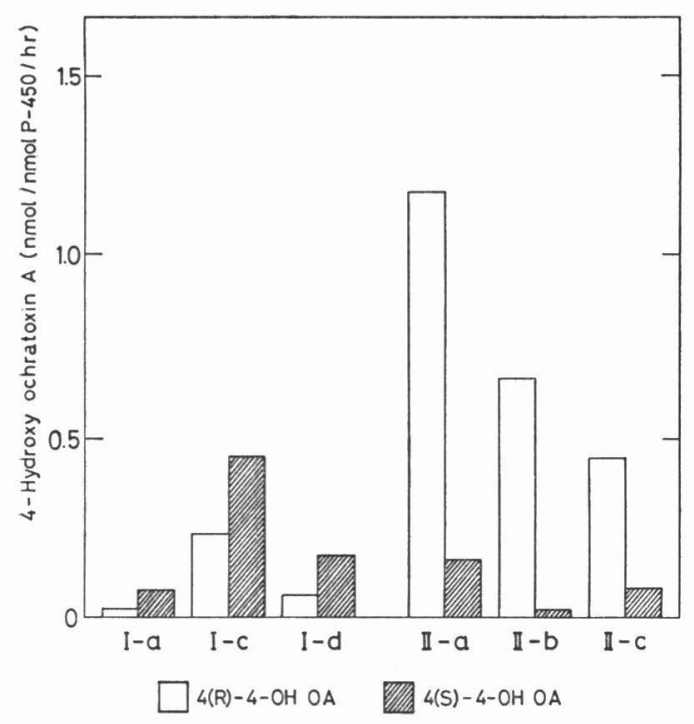

Fig. 3. Metabolic transformation of ochratoxin $\mathrm{A}$ in the reconstituted $\mathrm{P}-450$ system

7. $0^{3)}$, respectively, the optimal $\mathrm{pH}$ for hydroxylation reaction is presumed to be dependent on the substrates used.

In the experiments with the reconstituted cytochrome P-450 system, formation of 4(R)-4hydroxy-OA was the highest with cytochrome P450 II-a, and followed by II-b and II-c, as shown in Fig. 3. The type I isozymes also catalyzed this reaction but their activity was far less than the type II. Formation of $4(\mathrm{~S})$-4-hydroxy-OA was observed in the various cytochrome P-450 isozymes, and the highest activity was demonstrated with P-450 I-c, and followed by I-d. The present data showed that cytochrome P-450 isozymes catalyzed the stereospecific hydroxylation of $\mathrm{OA}$, and cytochrome P-450 II-a plays an principal role for the formation of $4(\mathrm{R})$-4-hydroxy-OA, a major metabolite in the hepatic microsomes of rats.

As summarized in Table 1 , the cytochrome P450 I isozymes (a-d) produced no detectable amount of 2-hydroxy-EM by TLC analysis. On the other hand, cytochrome P-450 II-a produced 2-hydroxy-EM (35 nmol/nmol P-450/20 min), and other II-type isozymes produced this direct-acting mutagen but their activity was far less than II-a.
Table 1. Formation of 2-hydroxy-emodin in the reconstituted cytochrome $\mathrm{P}-450$ system

\begin{tabular}{ccc}
\hline $\begin{array}{c}\text { Cytochrome } \\
\text { P-450 } \\
\text { isozymes }\end{array}$ & $\begin{array}{c}\text { Maximal CO- } \\
\text { difference } \\
\text { spectra (nm) }\end{array}$ & $\begin{array}{c}\text { 2-Hydroxy-EM } \\
\text { formed (nmol/nmol } \\
\text { P-450/20 min) }\end{array}$ \\
\hline I- a & 450.0 & ND* \\
I-b & 452.0 & ND \\
I- c & 450.0 & ND \\
I-d & 450.0 & ND \\
II- a & 448.0 & 35.0 \\
II- b & 449.5 & 7.9 \\
II- c & 447.0 & 7.9 \\
II-d & 447.5 & 3.5 \\
\hline
\end{tabular}

* ND: not detected.

Thus, the cytochrome P-450 II-a is the major isozyme in biotransformation of EM into a directacting mutagen, 2-hydroxy-EM.

Summing up the preceding ${ }^{1,4)}$ and present data, the cytochrome P-450 II-a, characterized by maximal CO-differential spectrum at $448.0 \mathrm{~nm}$ and a high-spin form, has a high activity in the hydroxylation of $\mathrm{AFB}_{1}, \mathrm{OA}$, and $\mathrm{EM}$ into $\mathrm{AFM}_{1}$, 4 (R)-4-hydroxy-OA, and 2-hydroxy-EM, respectively, and the reconstituted cytochrome P-450 system is useful for analysis of the biotransformation reaction of mycotoxins and other environmental toxins.

\section{References}

1) Ueno, Y., Ishii, K., Omata, Y., Kamataki, T., Kato, R.: Carcinogenesis, 4, 1071 (1983).

2) Ueno, Y., Tashiro, F., Haraikawa, K., Emi, Y.: In Tazima, Y. et al. eds., Problems in Threshold in Chemical Mutagenesis, The Environ. Mutagen Soc. Jpn., p. 61 (1984).

3) Masuda, T., Ueno, Y.: Mutation Res., 125, 135 (1983).

4) Masuda, T., Haraikawa, K., Morooka, N., Nakano, S., Ueno, Y.: Mutation Res., 149, 327 (1985).

5) Kamataki, T., Yamazoe, K., Masuda, N., Ishii, K., Kato, R.: Mol. Pharmacol., 24, 146 (1983).

6) Yoshizawa, H., Uchimaru, R., Kamataki, T., Kato, R., Ueno, Y.: Cancer Res., 42, 1120 (1982). 